\title{
INTERVENSI SIKAP KERJA DAPAT MENURUNKAN KELELAHAN KERJA DAN KELUHAN MUSKULOSKELETAL PADA KARYAWAN PT. SUCOFINDO CABANG DENPASAR
}

\author{
*Made Ary Pradnyawati ${ }^{1,2}$, I Ketut Tunas ${ }^{1}$, Ni Luh Gede Ari Natalia Yudha ${ }^{1}$ \\ ${ }^{1}$ Program Studi Kesehatan Masyarakat, Fakultas Ilmu Kesehatan, Sains, dan Teknologi Universitas \\ Dhyana Pura. ${ }^{2}$ PT. Superitending Company of Indonesia (PT.SUCOFINDO) Cabang Denpasar \\ *Email : arypradnyawati@gmail.com
}

\begin{abstract}
ABSTRAK
Salah satu akibat yang dapat disebabkan oleh gangguan musculoskeletal adalah menurunnya kinerja karyawan karena mengeluh sakit pada pundak, pantat, pinggang dan cepat lelah. Apabila keluhan tersebut tidak diatasi, maka akan berakibat pada timbulnya gangguan musculoskeletal. Penelitian ini bertujuan untuk mengetahui tingkat kelelahan kerja, tingkat keluhan musculoskeletal dan mengetahui penurunan kelelahan setelah dilakukan intervensi sikap kerja pada karyawan PT. Sucofindo Cabang Denpasar.Hasil penelitian terhadap 30 responden sebelum intervensi didapatkan 23 responden (77\%) yang masuk kategori lelah ringan dan 7 responden (23\%) masuk kategori lelah sedang. Setelah diberikan intervensi sikap kerja didapatkan 28 responden (90\%) masuk kategori lelah ringan dan 2 responden (10 \%) masuk kategori lelah sedang. Secara statistik terjadi perbedaan signifikan yang ditunjukkan dengan penurunan nilai mean dari 54,63 (sebelum intervensi) menjadi 50,13 (setelah intervensi). Untuk keluhan muskoskeletal berdasarkan penelitian dapat dilihat sebelum intervensi sikap kerja, sebanyak 26 responden (87\%) mengalami sakit ringan dan 4 responden $(13 \%)$ mengalami sakit sedang. Setelah intervensi sikap kerja didapatkan 29 responden (90\%) mengalami sakit ringan dan 1 responden (10\%) mengalami sakit sedang. Secara statistik terjadi perbedaan signifikan yang ditunjukkan dengan penurunan nilai mean dari 45,97 (sebelum intervensi) menjadi 41,13 (setelah intervensi). Kesimpulan dari hasil penelitian ini adalah intervensi sikap kerja dapat menurunkan kelelahan dan keluhan musculosceletal pada karyawan di PT. Sucofindo Cabang Denpasar.
\end{abstract}

Kata kunci : kelelahan, keluhan, musculoskeletal, intervensi, sikap kerja

\begin{abstract}
One of the consequences that may be caused by musculoskeletal disorders is decreasing the performance of the employee for complaining of pain in the shoulders, buttocks, waist and tired quickly. If a complaint is not resolved, it will result in the emergence of musculoskeletal disorders. This study aims to determine the level of fatigue, musculoskeletal complaints and determine the level of reduction in fatigue after intervention on the work attitude of employees of PT. Sucofindo Branch Office. The study, of 30 respondents before the intervention found 23 respondents (77\%) were categorized as mild tired and 7 respondents (23\%) in the category of being tired. After being given the intervention work attitude obtained 28 respondents (90\%) categorized as mild fatigue and 2 respondents (10\%) categorized as being tired. The difference was statistically significant as indicated by a decrease in the mean value of 54.63 (prior intervention) to 50,13 (after the intervention). For complaints muskoskeletal based research can be seen before the intervention work attitude, as much as 26 respondents (87\%) exper ienced mild pain and 4 respondents (13\%) had moderate pain. After the intervention of the working attitude obtained 29 respondents (90\%) experienced mild pain and one of the respondents (10\%) had moderate pain. The difference was statistically significant as indicated by a decrease in the mean value of 45.97 (prior intervention) to 41.13 ( after the intervention). It can be concluded that the intervention work attitude can reduce fatigue and complaints musculosceletal on employees at PT. Sucofindo Branch Office.
\end{abstract}

Keywords: fatigue, complaints, musculoskeletal, intervention, work attitude 


\section{PENDAHULUAN}

PT. Sucofindo adalah salah satu BUMN (Badan Usaha Milik Negara) yang berkecimpung dalam bidang jasa yaitu jasa inspeksi, warehousing dan forwarding, jasa analytical laboratories, industrial and marine engineering, dan fumigation and industrial hygiene. Dalam menjalankan pekerjaan di PT. Sucofindo Cabang Denpasar, kegiatan dibagi menjadi dua bidang yaitu Bidang Operasional dan Bidang Dukungan Bisnis. Kegiatan di bidang operasional adalah kegiatan inspeksi produk batubara, verifikasi ekspor, analisa laboratorium, dll. Sedangkan, bidang dukungan bisnis jenis kegiatannya adalah menjalankan fungsi pendanaan, pengelolaan dana operasional, perpajakan, perencanaan, pengembangan sumber daya manusia dan organisasi. Banyaknya jasa-jasa yang dilayani oleh PT. Sucofindo Cabang Denpasar menuntut karyawan bekerja secara optimal. Sebagian besar kegiatan yang dilakukan di Kantor PT. Sucofindo Cabang Denpasar dilakukan di kantor. Pekerjaan di kantor menuntut karyawan bekerja dengan sikap kerja statis. Sikap kerja statis adalah kondisi kerja duduk menggunakan komputer dengan punggung membungkuk. Kroemer \& Grandjean (2000) menyatakan bahwa sikap kerja statis dalam jangka waktu yang lama lebih cepat menimbulkan keluhan pada sistem musculoskeletal.

Dari survey awal yaitu wawancara singkat yang dilakukan terhadap karyawan di PT. Sucofindo Cabang Denpasar, sebanyak 7 karyawan mengeluh sakit pada pundak, pantat, pinggang dan cepat lelah. Sebagian besar dari mereka mengatasi hal tersebut dengan meminum jamu atau membiarkan saja, menganggap sebagai bagian dari risiko pekerjaan yang sewajarnya untuk diterima. Posisi kerja sehari-hari yang dilaksanakan oleh para karyawan yaitu bekerja duduk dengan menggunakan computer dan jarang melakukan pergerakan yang dinamis, kemungkinan keluhan musculoskeletal dan kelelahan kerja akan banyak ditemukan.

Berbagai gangguan kesehatan yang diakibatkan oleh pemakaian computer antara lain menurunkan ketajaman mata dan sakit kepala, gangguan penglihatan, sakit punggung dan leher, sakit pada tangan, pergelangan tangan dam bahu, ketegangan otot, kelelahan, rasa nyeri (Kroemer and Grandjean, 2000). Gangguan tersebut terjadi karena kerja otot yang cepat serta berulangulang sehingga menimbulkan kelelahan (Widiastuti, 2005). Selain itu sikap kerja dengan posisi duduk dalam waktu yang lama dapat menimbulkan nyeri otot rangka akibat kerja. Apabila sikap duduk dilakukan dengan keliru maka dapat menyebabkan adanya masalah punggung (Nurmianto, 2008).

Menurut penelitian Santoso dan Noeroel (2015), postur kerja yang salah dapat menjadi faktor penyebab atau memperparah keluhan musculoskeletal. Kelelahan dan keluhan musculoskeletal dapat menurunkan kinerja dan menambah kesalahan kerja karena hilangnya konsentrasi dan hilangnya jam kerja akibat rasa sakit yang diderita. Suma'mur (1989) menjelaskan bahwa keluhan pada tulang belakang yang dialami pekerja jika terus dibiarkan berpeluang besar menyebabkan dislokasi bagian tulang punggung yang menimbukan rasa sangat nyeri dan dapat mengakibatkan ireeversible fatal. Rasa sakit yang mengganggu sistem musculoskeletal pada saat bekerja dapat menyebabkan pecahnya lempeng dan bahan atau bagian dalam yang menonjol keluar serta mungkin menekan saraf-saraf disekitarnya, hal tersebut yang menyebabkan cidera atau bahkan menyebabkan kelumpuhan. Rasa nyeri pada tubuh juga secara psikologis dapat menyebabkan menurunnya tingkat kewaspadaan dan kelelahan akibat terhambatnya fungsi-fungsi kesadaran otak dan perubahan-perubahan pada organ-organ diluar kesadaran sehingga berpotensi menimbulkan kecelakaan dan penyakit akibat kerja.

Irwanti (2011) menyebutkan bahwa peregangan otot dapat menurunkan kebosanan $(18,54 \%)$, menurunkan kelelahan $(53,07 \%)$ dan menurunkan keluhan musculoskeletal $(64,8 \%)$ pada peserta didik kelas X di SMK Pariwisata Triatmajaya Badung. Berdasarkan hal tersebut maka peneliti tertarik melakukan penelitian berupa intervensi sikap kerja dapat menurunkan kelelahan dan keluhan musculoskeletal di PT. Sucofindo Cabang Denpasar.

\section{METODE}

Penelitian ini adalah penelitian eksperimental menggunakan rancangan sama subjek (treatment by subjects design) (Bakta, 2000). Rancangan sama subjek adalah rancangan serial, dimana semua sampel mengalami aktivitas dua periode 
dalam waktu yang berbeda. Sampel yang mendapat perlakuan adalah sampel yang sama. Dalam rancangan ini dibagi menjadi 3 tahap, yaitu periode 0 , washing out periode dan periode 1 . Periode 0 yaitu responden bekerja tanpa diberikan intervensi sikap kerja. Washing out periode berfungsi untuk menghilangkan efek perlakuan pada periode 0 , kegiatan yang dilakukan pada tahap washing out periode adalah responden bekerja seperti biasa dan disarankan untuk tidak mengambil jam lembur. Periode 1 yaitu responden bekerja dengan mendapat intervensi sikap kerja. Tiap periode dilakukan pada pukul 08.00 dan 15.00 selama 3 hari.

Jumlah sampel sebanyak 30 responden yang dipilih dengan metode random sampling. Data yang diambil adalah data sebelum dan setelah bekerja, adapun data yang diukur adalah kelelahan kerja dan keluhan musculoskeletal. Kelelahan kerja diukur dengan menggunakan kuesioner 30 kelelahan subyektif umum dan keluhan musculoskeletal diukur menggunakan kuesioner Nordic Body Map.

\section{HASIL}

Berdasarkan penelitian yang dilakukan terhadap 30 responden sehubungan dengan kelelahan kerja sebelum dan sesudah intervensi sikap kerja, maka didapatkan hasil seperti yang tertera pada Tabel 1.

Tabel 1. Kelelahan Kerja Sebelum dan Sesudah Intervensi Sikap Kerja

\begin{tabular}{lllll}
\hline & $\begin{array}{l}\text { Sebelum } \\
\text { Intervensi }\end{array}$ & $\begin{array}{l}\text { Setelah } \\
\text { Intervensi }\end{array}$ \\
\hline Kategori Kelelahan & $\mathrm{n}$ & $\%$ & $\mathrm{~N}$ & $\%$ \\
\hline Tidak Lelah & 0 & 0 & 0 & 0 \\
Lelah Ringan & 23 & 77 & 28 & 90 \\
Lelah Sedang & 7 & 23 & 2 & 10 \\
Lelah Berat & 0 & 0 & 0 & 0 \\
\hline
\end{tabular}

Berdasarkan Tabel 1. dapat dilihat bahwa sebelum Intervensi sikap kerja, tidak ada responden yang masuk dalam kategori tidak lelah dan lelah berat, 23 responden (77\%) yang masuk kategori lelah ringan dan 7 responden $(23 \%)$ masuk kategori lelah sedang. Setelah diberikan intervensi sikap kerja didapatkan 28 responden (90\%) masuk kategori lelah ringan dan 2 responden (10 $\%)$ masuk kategori lelah sedang.

Pada penelitian ini juga dihitung perbandingan nilai kelelahan kerja sebelum dan setelah intervensi sikap kerja, yang hasilnya dapa dilihat pada Tabel 2 .

Tabel 2. Perbandingan nilai Kelelahan Kerja Sebelum dengan Sesudah Intervensi

\begin{tabular}{lllll}
\hline Periode & $\mathrm{n}$ & Mean & Std. Deviation & $\mathrm{p}$ \\
\hline Sebelum Intervensi & 30 & 54.63 & 8.712 & \\
Sesudah Intervensi & 30 & 50.13 & 7.767 & 0.011 \\
\hline
\end{tabular}

Berdasarkan Tabel 2. Dapat dilihat bahwa terjadi perbedaan secara signifikan antara periode 0 (sebelum dilaksanakan intervensi sikap kerja) dengan periode 1 (setelah dilakukan intervensi sikap kerja). Hasil mean menyatakan ada penurunan kelelahan dari sebelum dilaksanakan intervensi sikap kerja dengan setelah dilakukan intervensi sikap kerja.

Pada penelitian ini juga dilihat perbedaan keluhan musculoskeletal sebelum dan sesudah intervensi sikap kerja, yang hasilnya dapat dilihat pada Tabel 3. 
Tabel 3. Keluhan Muskuloskeletal Sebelum dan Sesudah Intervensi Sikap Kerja

\begin{tabular}{lllll}
\hline & $\begin{array}{l}\text { Sebelum } \\
\text { Intervensi }\end{array}$ & \multicolumn{3}{l}{$\begin{array}{l}\text { Setelah } \\
\text { Intervensi }\end{array}$} \\
\hline Kategori Keluhan musculoskeletal & $\mathrm{N}$ & $\%$ & $\mathrm{n}$ & $\%$ \\
\hline Tidak Sakit & 0 & 0 & 0 & 0 \\
Sakit Ringan & 26 & 87 & 29 & 90 \\
Sakit sedang & 4 & 13 & 1 & 10 \\
Sakit Berat & 0 & 0 & 0 & 0 \\
\hline
\end{tabular}

Berdasarkan Tabel 3. dapat dilihat bahwa dari 30 responden sebelum intervensi sikap kerja, sebanyak 26 responden $(87 \%)$ mengalami sakit ringan dan 4 responden (13\%) mengalami sakit sedang. Setelah intervensi sikap kerja didapatkan 29 responden (90\%) mengalami sakit ringan dan 1 responden (10\%) mengalami sakit sedang.

Pada penelitian ini juga dilihat perbandingan nilai keluhan muskuloskeletal sebelum dengan sesudah intervensi sikap kerja, yang hasilnya dapat dilihat pada Tabel 4.

Tabel 4. Perbandingan nilai Keluhan Muskuloskeletal sebelum dengan sesudah Intervensi

\begin{tabular}{lllll} 
Periode & $\mathrm{N}$ & Mean & Std. Deviation & Sig.(2-tailed) \\
\hline Sebelum Intervensi & 30 & 45.97 & 8.006 & \\
Sesudah Intervensi & 30 & 41.13 & 7.851 & 0.011
\end{tabular}

Bedasarkan Tabel 4. didapatkan bahwa terjadi perbedaan secara signifikan antara periode 0 (sebelum dilaksanakan intervensi sikap kerja) dengan periode 1 (setelah dilakukan intervensi sikap kerja). Hasil mean menyatakan ada penurunan kelelahan dari sebelum dilaksanakan intervensi dengan setelah dilakukan intervensi sikap kerja.

\section{PEMBAHASAN}

Tingkat kelelahan pada penelitian ini diukur menggunakan kuesioner 30 kelelahan umum. Dari hasil kuesioner didapatkan, karakteristik responden dikelompokkan berdasarkan jenis kelamin, kelompok umur, dan masa kerja, sedangkan kelelahan disini dikelompokkan menjadi 4 kategori yaitu kategori tidak lelah, lelah ringan, lelah sedang dan lelah berat.

Menurut Grandjean (1993) bahwa puncak kekuatan otot dicapai pada umur 2535 tahun. Kekuatan otot akan menurun pada usia 39 tahun dan pada usia 60 tahun kapasitas aerobik dan kekuatan otot hanya tinggal $70 \%$ dibandingkan pada usia 25 tahun (Bridger, 1995). Berdasarkan hal tersebut maka karakteristik responden untuk umur, dibedakan menjadi dewasa muda (2035 tahun) dan dewasa tua (36-60 tahun). Hasil penelitian kelompok umur dewasa tua (36-60 tahun) lebih banyak mengalami kelelahan dengan kategori lelah sedang yaitu
4 responden (13\%) dibandingkan dengan kelompok umur dewasa muda sebanyak 3 responden (10\%). Hasil penelitian ini sesuai dengan penelitian Tarwaka (2004) bahwa seiring dengan meningkatnya umur seseorang akan diikuti dengan perkembangan organ-organ dalam tubuh yang akan mengalami proses degenerasi diserti penurunan fungsi organ tersebut.

Berdasarkan masa kerja yang paling tinggi mengalami kelelahan pada kategori lelah sedang adalah kelompok masa kerja karyawan baru (0-10 tahun) yaitu sebesar 4 responden (13.33\%) sedangkan kelompok masa kerja professional sebesar 3 responden (10\%). Menurut Ratih (2012) Prevalensi kelelahan berdasarkan masa kerja dan tingkat pengalaman seseorang dalam suatu pekerjaan akan mempengaruhi kejadian kelelahan orang tersebut. $\mathrm{Hal}$ ini dikarenakan semakin berpengalaman orang tersebut dalam pekerjaannya, efisiensinya dalam bekerja juga meningkat. Semakin lama bekerja maka dianggap dapat mengatur besarnya tenaga yang dikeluarkan oleh karena seringnya mengambil pekerjaan yang sama. Selain itu orang yang sudah bekerja pada masa kerja yang lama sudah mengetahui posisi yang nyaman untuk dirinya sehingga dapat mengatur kelelahannya. 
Kelelahan akibat kerja sering diartikan sebagai proses menurunnya efisiensi, performa kerja dan berkurangnya kekuatan atau ketahanan fisik tubuh untuk terus melanjutkan kegiatan yang harus dilakukan (Sritomo Wignjosoebroto, 2003). Pada kondisi sehat, tenaga kerja akan lebih cepat merespon rangsangan yang diberikan dan seseorang yang telah mengalami kelelahan akan lebih lama merespon rangsangan yang diberikan (A.M. Sugeng Budiono, dkk., 2000). Eko Nurmianto (2003) menyatakan bahwa semua jenis pekerjaan akan menghasilkan kelelahan kerja. Kelelahan kerja akan menurunkan kinerja dan menambah tingkat kesalahan kerja.

Perbandingan hasil penelitian sebelum dilakukan intervensi sikap kerja dengan setelah dilakukan intervensi sikap kerja didapatkan adanya penurunan angka kelelahan yaitu kategori lelah sedang pada responden yaitu $28.6 \%$. Hasil penelitian ini serupa dengan penelitian yang dilakukan oleh Putri (2012) yaitu dengan pemberian makanan tambahan dapat mengurangi nilai kelelahan kerja pada pekerja UD. Anggraini dimana pemberian makan pada saat-saat istirahat dapat membantu memperbaiki produktivitas dan meniadakan kelelahan kerja. Selain itu hasil penelitian ini juga diperkuat oleh penelitian dari Irwanti (2012), bahwa pemberian peregangan otot peserta didik kelas X SMK Pariwisata Triatma Jaya di sela pembelajaran dapat menurunkan kelelahan secara bermakna yaitu $53.07 \%$.

Dalam penelitian ini, intervensi sikap kerja dengan pemberian makanan ringan disela-sela jam kerja dapat menurunkan kelelahan kerja karena pemberian makanan tambahan bagi tenaga kerja dalam bentuk makanan ringan akan membantu pekerja dalam mempertahankan stamina dan kemampuan kalori sampai waktu makan berikutnya. Sesuai dengan teori Putri (2012) yaitu pemberian makanan tambahan diantara waktu makan pagi dan siang dimaksudkan untuk tetap mempertahankan kadar glukosa dalam darah, sehingga dapat mempertahankan kondisi tubuh agar tidak menurun. Selingan makanan demikian diberikan setelah 2 jam bekerja oleh karena pada kondisi tersebut persediaan kalori dalam tubuh berkurang atau mungkin habis digunakan untuk keperluan bekerja (Suma'mur, 2009).
Pada penelitian ini diberikan pelatihan peregangan pada sela-sela bekerja pada jam 10 pagi dan jam 3 sore. Sesuai dengan pendapat Anderson (2010), peregangan dapat dilakukan pada saat bekerja untuk melepaskan ketegangan syaraf. Menurut Anderson (2010) peregangan adalah aktivitas yang dapat membuat tubuh merasa lebih baik. Masalah keluhan muskulosekeletal dapat diatasi dengan ergonomi, namun tubuh tetap menderita akibat duduk dan diam dalam waktu yang lama sehingga dibutuhkan peregangan otot. Peregangan teratur di sela-sela pekerjaan akan bermanfaat untuk mengurangi ketegangan otot, memperbaiki peredarah darah, mengurangi kecemasan dan membuat tubuh merasa lebih baik

Keluhan musculoskeletal diprediksi berdasarkan kuesioner Nordic Body Map. Hasil penelitiandidapatkan bahwa responden mengalami keluhan sakit yang paling sering adalah bagian punggung (11.1\%), lengan $(5,48 \%)$, bahu $(3,9 \%)$ leher $(3,7 \%)$, punggung bawah $(3,5 \%)$, betis $(3,3)$, pergelangan tangan $(3,02)$, paha $(3 \%)$, lutut (3\%), dan kaki $3 \%$.

Prosentase yang paling tinggi keluhan sakit pada karyawan PT. Sucofindo Cabang Denpasar adalah keluhan sakit pada bagian punggung. Tingginya prosentase keluhan sakit pada punggung dapat disebabkan oleh sikap kerja duduk sepanjang hari dan sikap duduk yang keliru. Nyeri punggung terjadi karena sikap duduk yang keliru dan kurangnya duduk dengan menyandar pada sandaran kursi(Santoso,2004).

Keluhan pada bagian lengan yang dirasakan oleh responden dari hasil observasi karena tidak adanya sandaran tangan pada kursi. Keluhan pada bagian bahu yang dirasakan oleh responden terjadi karena responden menggunakan komputer dengan posisi tubuh tidak tegak dan tidak bersender pada sendaran kursi sehingga menyebabkan otot-otot bahu menjadi tegang dan pegal. Dalam bekerja, faktor tempat duduk sangat penting karena dengan tempat duduk yang nyaman kita dapat bekerja dengan baik dan sehat. (Suma'mur, 2009).

Keluhan pada bagian leher yang dirasakan oleh responden dapat terjadi karena saat menggunakan komputer, sudut yang dibentuk kepala ketika melihat layar komputer lebih dari 20 derajat atau kepala mnunduk, sehingga menyebabkan otot menjadi cepat tegang. Posisi kepala yang 
terlalu menunduk dikarenakan posisi meja tidak sesuai dengan antropometri tubuh. Selain itu keluhan pada leher juga disebabkan oleh sikap kerja statis. Ariens, dkk (2001) menyatakan bahwa pekerja yang bekerja dalam posisi duduk yg statis $>95 \%$ dari lamanya waktu bekerja per satu hari merupakan faktor risiko yang berkaitan dengan keluhan sakit pada leher.

Keluhan pada bagian pergelangan tangan yang dirasakan oleh responden diakibatkan oleh pergelangan tangan yang terus menerus menekuk dapat menyebabkan saraf lokal mengalami inflamasi dan terperangkap sehingga muncul keluhan nyeri pergelangan tangan dan rasa sensasi kesemutan pada tangan (Dul Jan, dkk., 2001).

Hasil penelitian diperoleh gangguan musculoskeletal pada region tungkai bawah atau lower extremity didapatkan lebih rendah. Hal ini sesuai dengan teori yang menyatakan karyawan yang menggunakan computer bekerja dengan posisi duduk merasa lebih nyaman, karena kurangnya kelelahan pada kaki dan pemakaian energy yang rendah (Wasisto, 2005). Menurut Korhan (2012), beberapa penelitian epidemiologi menunjukkan bahwa pekerjaaan yang berhubungan dengan penggunaan komputer memiliki risiko yang tinggi berkembangnya gejala-gejala musculoskeletal.

Berdasarkan responden yang paling sering mengalami keluhan musculoskeletal dikategorikan berdasarkan kelompok umur. Dalam hal ini kelompok umur yang paling sering mengalami keluhan musculoskeletal kategori sakit sedang adalah kelompok umur dewasa tua (36-60 tahun) sebanyak 3 responden (10\%). Hasil penelitian ini sebanding dengan Chaffin (1979) yang menyatakan bahwa pada umumnya keluhan otot musculoskeletal mulai dirasakan pertama pada umur 35 tahun dan tingkat keluhan akan terus meningkat sejalan dengan bertambahnya umur.

Berdasarkan data responden, yang paling sering mengalami keluhan musculoskeletal kategori sedang adalah responden pada kelompok masa kerja professional yaitu 3 responden, sedangkan responden pada kelompok masa kerja karyawan baru sebanyak 1 responden. Hasil ini sejalan dengan penelitian Hendra (2009) tentang keluhan muskuloskeletal pada pekerja yang telah lama bekerja lebih tinggi mengalami keluhan muskuloskeletal yaitu $70 \%$ mengalami keluhan muskuloskeletal berat dibandingkan pekerja yang baru sebesar $23.5 \%$.

Intervensi sikap kerja merupakan salah satu upaya untuk menurunkan adanya keluhan musculoskeletal. Intervensi sikap kerja yang dilakukan pada penelitian ini adalah melakukan peregangan otot diselasela jam kerja dan pemberian makanan ringan.

Tabel 4 menunjukkan bahwa hasil signifikan 0.011, mempunyai makna yaitu setelah melakukan peregangan otot dan pemberian makanan ringan disela-sela jam kerja terjadi perbedaan yang bermakna $(p<0.05)$. Hasil menunjukkan terdapat perbedaan yang signifikan antara nilai $\mathrm{p} 0$ (sebelum dilakukan intervensi sikap kerja) dengan p1 (setelah dilakukan intervensi sikap kerja). Dari hasil tersebut dapat disimpulkan bahwa ada penurunan keluhan musculoskeletal setelah dilakukan intervensi sikap kerja.

Hasil penelitian menunjukkan bahwa responden dengan keluhan musculoskeletal kategori sedang sebanyak $13 \%$, menurun menjadi $10 \%$ setelah dilakukan intervensi sikap kerja. Prosentase penurunan keluhan musculoskeletal sebelum dilakukan intervensi sikap kerja dibandingkan dengan setelah intervensi sikap kerja sebesar $25 \%$. Hasil penelitian ini sejalan dengan penelitian Indrawati (2015) yaitu pelatihan peregangan otot menurunkan keluhan musculoskeletal $71,98 \%$ pada karyawan rekam medis Rumah Sakit Sanglah Denpasar.

Sakit pada sistem mukuloskeletal dapat disebabkan karena sikap statis, sehingga aliran darah ke otot tersebut menurun. Suplai oksigen yang menurun pada bagian otot akan menyebabkan proses aerobik untuk pembentukan energi di otot tersebut tidak dapat terjadi. Hal ini menyebabkan tubuh menyeimbangkannya dengan melakukan proses pembentukan energi anaerobik yang mengubah glukosa menjadi laktat. Laktat ini nantinya dapat menumpuk pada otot yang dapat menyebabkan otot menjadi lelah dan terasa pegal. Untuk membuang sisa laktat di dalam tubuh dan mengurangi rasa pegal pada otot, diperlukan oksigen adekuat yang dapat diperoleh melalui peregangan tubuh (Ganong, 2008). Peregangan tubuh saat bekerja berfungsi untuk melancarkan peredaran darah di tubuh sehingga suplai oksigen ke seluruh tubuh terpenuhi (Nugroho, 2007). Selain itu pemberian 
makanan terhadap keluhan muskuloskeletal perlu dilakukan karena produktivitas dalam bekerja biasanya akan mulai menurun setelah 4 jam bekerja. Keadaan ini sejalan dengan menurunnya kadar gula dalam darah, maka perlu istirahat dengan melakukan makan guna meningkatkan kembali energi dan kadar gula darah ( Suma'mur, 1996 ).

\section{KESIMPULAN}

Dari hasil penelitian diatas maka dapat disimpulkan bahwa tingkat kelelahan ringan pada karyawan PT. Sucofindo Cabang Denpasar sebelum dilakukan intervensi sikap kerja sebanyak $77 \%$ dan yang mengalami lelah ringan sebanyak $23 \%$. Terdapat penurunan kelelahan kerja sebesar $28.6 \%$ setelah dilakukan intervensi sikap kerja. Tingkat keluhan musculoskeletal ringan pada karyawan PT. Sucofindo Cabang Denpasar sebelum dilakukan intervensi sikap kerja sebanyak $87 \%$ dan keluhan musculoskeletal sedang sebanyak 13\%. Terdapat penurunan keluhan musculoskeletal sebesar $25 \%$ setelah dilakukan intervensi sikap kerja.

\section{DAFTAR PUSTAKA}

Anderson, B. 2010. Stertching In The Office, peregangan untuk orang kantoran. Jakarta. PT. Serambi Ilmu Semesta.

Ariens GAM, dkk. 2001. Are neck flexion, neck rotation, and sitting at work risk factors for neck pain. Result of a prospective cohort studi. Occup Environ Med.

Bakta. 2000. Uji Klinik. Majalah Penyakit Dalam Udayana Vol. I (2)

Bridger, R.S. 1995. Introduction to Ergonomics. Singapore: McGraww Hill, Inc.

Dul, Jan., dkk. 2001. Ergonomic for Beginners : A Quick Reference Guide Second Edition. New York. Taylor \& France

Ganong, W. F. 2008. Buku Ajar Fisiologi Kedokteran Edisi22 .Jakarta : EGC.

Grandjean. Etienne. 1993. Fitting the task to the man. London. Taylor \& Francis

Indrawati, Eko Putu dkk.,. 2015. Pelatihan Peregangandan Istirahat Aktif dapat menurunkan keluhan Muskuloskeletal, kelelahan Mata dan Meningkatkan Konsentrasi Kerja Karyawan Rekam Medis Rumah Sakit Sanglah. Vol 1, No 1.Jurnal Ergonomi Indonesia.
Irwanti Dewi Ni Ketut. 2011. Peregangan otot di Sela Pembelajaran Mengurangi Kebosanan, Kelelahan, dan Keluhan Muskuloskeletal peserta didik kelas X, SMK Pariwisata Triatma Jaya Badung. Tesis. Program Pasca Sarjana Universitas Udayana

Korhan, Orhan. 2012. Work-Related Muskuloskeletal Discomfort in the Shoulder due to Computer Use. Departement of Industrial Engineering.Eastern Mediterranean University, North Cyprus, Mersin. Turkey.

Kroemer, K. H. E dan Grandjean, E. 2000. Fitting the Task to the Man, A Textbook of Occupational Ergonomics. $5^{\text {th }}$ Edition. London : Taylor \& Francis.

Nugroho, R. 2007. Tingkat Pengetahuan Mahasiswa Fakultas Kesehatan Masyarakat Universitas Indonesia Mengenai Cara dan Dampak Penggunaan Laptop. Skripsi. Depok : Fakultas Kesehatan Masyarakat Universitas Indonesia.

Nurmianto E. 2003. Ergonomi Konsep Dasar dan Aplikasinya. Surabaya : Institut teknologi Sepuluh Nopember

Nurmianto E. 2008. Ergonomi Konsep Dasar dan Aplikasinya. Surabaya :GunaWidya

Putri,D.W.,.2012. Pengaruh pemberian makanan tambahan terhadap kelelahan kerja pada pekerja di UD. ANGGRAINI. Program diploma keselamatan kerja Fakultas Kedokteran. Universitas Sebelas Maret : Surakarta.

Ratih Arini Dewi. 2012. Hubungan Antara Kelelahan Kerja dengan Stress Kerja pada Tenaga Kerja Bagian Weaving PT. Iskandar Indah Printing Textile Surakarta. Program Diploma IV Keselamatan dan Kesehatan Kerja Fakultas Kedokteran Universitas Sebelas Maret : Surakarta.

Santoso, G. 2004. Ergonomi Manusia, Peralatan dan Lingkungan. Cetakan I Jakarta : Prestasi Pustaka

Sritomo, W. 2003. Ergonomi Studi Gerak dan Waktu. Surabaya :GunaWidya

Sugeng Budiono, dkk. 2000. Bunga Rampai Hiperkes dan KK. Semarang : BP Universitas Dipenogoro 
Suma'mur P.K (1989). Ergonomic Untuk Meningkatkan Produktifitas Kerja. Jakarta : Prestasi Pustaka

Suma'mur P.K., 1996. Hiegiene Perusahaan dan Kesehatan Kerja. Cet-6. Jakarta: Gunung Agung

Suma'mur P.K., 2009. Hiegiene Perusahaan dan Keselamat Kerja. Jakarta: Sagung Seto

Tarwaka. 2004. Ergonomi untuk Keselamatn, Kesehatan Kerja \& Produktivitas. Surakarta : Uniba Press.

Wasisto, Sigit W. 2005. Bekerja dengan Komputer Secara Ergonomis dan sehat,

http://www.wahanakom.com/infotek/e rgonomis.html.Tanggaldiakses 11 Juli $\underline{2016}$.

Widiastuti, M. I. 2005. Aspek Anatomi Terapan pada Pemahaman Neuro musculoskeletal Kepala dan Leher sebagai Landasan Penanganan Nyeri Kepala. Semarang : Tegang Prima 